\title{
KONSUMSI, AKTIVITAS RUMINASI DAN KECERNAAN IN VIVO SILASE RUMPUT RAJA DENGAN PENAMBAHAN ADITIF BIOMIKRO ${ }^{\circ}$
}

\author{
E. Supurwaningdyah', R. Utomo ${ }^{2}$ dan A. Agus ${ }^{2}$
}

\section{INTISARI}

Penelitian ini dilakukan untuk mengetahui konsumsi, aktivitas ruminasi dan kecernaan in vivo rumput raja atau yang telah dibuat silase dengan bantuan aditif biologis Biomikro ${ }^{\circ}$ (BAB). Tiga ekor sapi PO yang telah dilengkapi dengan fistula rumen dibagi dalam dua kelompok perlakuan P1 yaitu : konsentrat $1 \%$ bobot badan + rumput raja $100 \%$ dan P2 : konsentrat $1 \%$ bobot badan + rumput raja 30\%'+70\% silase rumput raja. Silase dibuat dengan menambahkan $\mathrm{BAB}$ sebanyak 1,5\% bahan kering dan diinkubasikan selama 3 minggu. Penelitian dilaksanakan selama dua periode dengan rancangan cross over. Data yang diambil meliputi konsumsi pakan. waktu yang digunakan untuk aktifitas makan (chewing activity), ruminasi (lama dan frekuensi) serta kecemaan nutrien (BK, BO, PK, NDF, ADF). Data yang diperoleh dianalisis T-test dengan periode digunakan sebagai covariat, Konsumsi dan kecernaan BK, BO, PK, NDF dan ADF secara nyata lebih tinggi pada P2 dibanding P1 $(103,18 ; 93,38 ; 13,00 ; 52,07 ; 36,29 ;$ vs 85,$12 ; 73,83$; 11,$49 ; 42,19 ; 27,57 \mathrm{~g} / \mathrm{kg}$ bobot badan metabolik /hari) dan $(68,76 ; 70,37 ; 86,77,56,90 ; 53,08 \%$ vs 64,$14 ; 65,01 ; 79,09 ; 50,23 ; 36,82 \%$ ). Waktu untuk ruminasi per kg bahan kering pada P1 lebih lama $(\mathrm{P}<0,05)$ dibanding pada $\mathrm{P} 2\left(37,7\right.$ vs 35,2 menit). Rata-rata $\mathrm{pH}, \mathrm{NH}_{3}$ dan VFA pada $\mathrm{PI}$ dan $\mathrm{P} 2$, selama 24 jam pengamatan adalah 6,98 vs 6,$89 ; 104,134 \mathrm{mg} / \mathrm{t}$ vs $97,73 \mathrm{mg} / \mathrm{l}$ dan 89,08 $\mathrm{mmol} / \mathrm{l}$ vs $109,66 \mathrm{mmol} / \mathrm{l}$. Kinetika $\mathrm{pH}$ dan kadar $\mathrm{NH}_{3}$ rumen untuk $\mathrm{Pl}$ relatif lebih tinggi dibanding pada P2, sedangkan untuk kinetika VFA sebaliknya. Dapat disimpulkan bahwa konsumsi dan kecernaan rumput yang dibuat silase dengan aditif BAB lebih baik dibanding rumput tanpa dibuat silase, yang didukung pula oleh lebih baiknya aktivitas dan lama ruminasi dan parameter fermentasi rumen.

(Kata kunci : Sapi PO, Silase, Konsumsi, Kecernaan, Aktivitas ruminasi, Parameter fermentasi).

Buletin Petenakan 26 (4): $64-72,2002$

\footnotetext{
${ }_{2}^{1}$ Karyasiswa S2 Program Studi llmu Peternakan, Program Pascasarjana UGM.

${ }^{2}$ Fakultas Peternakan Universitas Gadjah Mada, Yogyakarta.
} 


\title{
INTAKE, ACTIVITY OF RUMINATION AND IN VIVO DIGESTIBILITY OF KING GRASS SILAGE ADDED BY BIOMIKRO ${ }^{\circ}$ ADDITIVE
}

\begin{abstract}
This experiment was conducted to determine feed intake, activity of rumination and in vivo digestibility of king grass silage made using biological additive Biomikro ${ }^{6}$ (BAB). Three Ongole crossbred fistulated cattle were alloted to two treatments : TI (concentrate $1 \%$ of BW + king grass $100 \%$ ) and TII (concentrate $1 \%$ of BW + king grass $30 \%+$ silage $70 \%$ ). Silage was prepared using $\mathrm{BAB} 1,5 \% \mathrm{DM}$ and incubated for 3 weeks. This experiment was conducted in two periods of time. The variables observed were intake, eating time, ruminating time, remastication and digestibility of DM, OM, CP, NDF and ADF. The collected were analyzed Student's T-test. The intake and digestibility of DM, OM, CP, NDF and ADF of TII were higher $(\mathrm{P}<0,01)$ than TI $\left(103,18,93,38,13,00 ; 52,07 ; 36,29 ;\right.$ vs 85,$12 ; 73,83 ; 11,49 ; 42,19 ; 27,57 \mathrm{~g} / \mathrm{kg}$ of $\mathrm{BW}^{0,75} /$ day $)$ and $(68,76 ; 70,37 ; 86,77 ; 56,90 ; 53,08 \%$ vs 64,$14 ; 65,01 ; 79,09 ; 50,23 ; 36,82 \%)$. Duration of eating time per kilogram of DM intake TI and TII were $57,7 \mathrm{~min}$ and $35,4 \mathrm{~min}(\mathrm{P}<0,01)$. Ruminating time per kilogram of DM intake TI was longer $(\mathrm{P}<0,05)$ than TII $(37,7 \mathrm{vs} 35,2), \mathrm{pH}, \mathrm{NH}_{3}$ and VFA of TI and TII during 24 hours were 6,98 vs 6,$89 ; 104,13 \mathrm{mg} / \mathrm{l}$ vs $97,73 \mathrm{mg} / \mathrm{l}$ and $89,08 \mathrm{mmol} / 1$ vs $109,66 \mathrm{mmol} / \mathrm{l}$ respectively. Kinetic of $\mathrm{pH}$ and $\mathrm{NH}_{3}$ for TI was relatively higher than TII, while the kinetic of VFA was lower. It could be concluded that feed intake and digestibility of silage made using $\mathrm{BAB}$ were higher than king grass.
\end{abstract}

(Key words: Ongole crossbred cattle, Silage, Additive of Biomikro ${ }^{x}$, Intake, Digestibility, Ruminal Fermentation).

\section{Pendahuluan}

Salah satu permasalahan dalam pengembangan peternakan di Indonesia adalah pakan, karena pakan merupakan faktor yang sangat berpengaruh terhadap peningkatan produksi ternak, sehingga dibutuhkan manajemen pakan yang baik meliputi kualitas, kuantitas maupun kontinuitas. Untuk ternak ruminansia kendala yang dihadapi dalam peningkatan populasinya terutama adalah penyediaan pakan hijauan. Hijauan pakan ternak di daerah tropik pada umumnya berfluktuasi mengikuti pola musim. Pada musim penghujan kuantitas hijauan pakan ternak melebihi kebutuhan ternak dan sebaliknya pada musim kemarau kuantitasnya sangat terbatas. Oleh karena itu perlu dilakukan konservasi hijauan pakan ternak untuk menjamin ketersediaan hijauan secara kontinyu. Salah satu cara yang dapat ditempuh untuk konservasi hijauan adalah melalui proses fermentasi anaerobik yang disebut silase (Van Soest, 1994).

Pada proses pembuatan silase diharapkan kehilangan nutrien hijauan akibat dekomposisi dapat diminimalkan. McDonald (1981) melaporkan bahwa kehilangan bahan kering (BK) dan nitrogen (N) pada proses pembuatan silase dapat mencapai $20 \%$. Penurunan ini disebabkan oleh adanya aktivitas enzimatis oleh sel tanaman dan adanya fermentasi aerobik. Selain itu penurunan kualitas juga disebabkan karena kurang cepatnya pencapaian $\mathrm{pH}$ dibawah 4,2 akibat lambatnya perkembangan bakteri asam laktat.

Ensilase meliputi pengubahan karbohidrat mudah larut hijauan menjadi asam laktat oleh bakteri asam laktat, sehingga proses ini yang berperan adalah karbohidrat mudah larut dan bakteri asam laktat. Mikroflora epifitik tanaman yang sedang tumbuh biasanya adalah mikroflora aerobik dan hanya sedikit yang anaerobik. Oleh karena itu jika hanya 
menggantungkan pada jumlah mikroflora tanaman yang memproduksi asam laktat maká ensilase tidak akan berjalan optimal (Harradi, 1992). Penambahan stimulan berupa kultur campuran yang mengandung bakteri asam laktat dan mikroorganisme selulolitik padia pembuatan silase merupakan langkah yang tepat untuk mengatasi permasalahan tersebut sehingga akan mempercepat penurunan $\mathrm{pH}$ dan kehilangan nutrien selama ensilase dapat diminimalkan Selanjutnya perlu dievaluasi tingkat palatabilitas dan kecernaah pakan hasil konservasi tersebut untuk mengetahui besarnya nutrien pakan yang dapat dimanfaatkan oleh ternak.

\section{Materi dan Metode}

Penelitian dilaksanakan di kandang funsan Nutrisi dan Makanan Ternak, Fakultas Peternakan, Universitas Gadjah Mada mulai bulan Ottober - Desember 2000, sedangkan analisis komposisi kimia dilakukan di Laboratorium Teknologi Makanan Ternak, Jurusan Nutrisi dan Makanan Ternak, Fakuitas Peternakan, Universitas Gadjah Mada

Aralisis komposisi kimia, yaitu BK dan bahan organik $(\mathrm{BO})$ menurut metode Weende, neutral detergent fiber (NDF) dan acid detergent fiber (ADF) dengan metode Goering dan Van Soest dilaksanakan di Laboratorium Teknologi Makanan Ternak, Junusan Nutrisi dan Makanan Ternak, Fakultas Peternakan, Universitas Gadjah Mada. Analisis kandungan protein kasar (PK) dilaksanakan di Laboratorium Biokimia, Fakultas Teknologi Pertanian, Universitas Gadjah Mada.

Penelitian ini menggunakan 3 ekor sapi Peranakan Ongole (PO) betina yang di fistula numen dengan berat badan sekitar $300 \mathrm{~kg}$ dan umur 2,5-3,0 tahun. Ransum yang digunakan terdiri dari hijauan yang berupa rumput raja, silase rumput raja dan konsentrat komersial. Konsentrat diperoleh dari pabrik makanan ternak Kamfeed. Rumput raja dengan umur protong \pm 50 hari diperoleh dari daerah Pleret, Kabupaten Dati II Bantul

Perlakuan pakan terdiri dari 2 macam yaitu

P 1 Kansentrat 1 \% BB/ekor/hari +
rumput raja $100 \%$

P 2 Konsentrat $1 \%$ BB/ekor/hari + rumput raja $30 \%+$ silase $70 \%$.

Rumput raja dengan umur pemotongan \pm 50 hari di potong-potong dengan chopper sepanjang 4-5 cm dan diangin-anginkan untuk mendapatkan kadar $\mathrm{BK} \pm 35 \%$. Rumput raja yang telah layu dengan kadar $\mathrm{BK} \pm 35 \%$ selanjutnya ditambah aditif biologis Biomiloro ( $\mathrm{ABB}$ ) dengan level 1,5\% BK dengan cara disemprotkan Rumput raja dimasukkan ke dalam silo yang tetbuat dari drum yang dilapisi plastik sedikit demi sedikit sambil diinjak-injak untuk memadatkan dan mengurangi oksigen dalam silo. Setelah silo terisi penuh, sisa oksigen didalam silo dikeluarkan dengan menggunakan pompa vakum. Silase di inkubasi selama 3 minggu. Jumlah pembuatan silase disesuaikan dengan kebutuhan ternak selama penelitian berlangsung yaitu $\pm 2000 \mathrm{~kg}$. Pembuatan silase dilakukan setiap 3 hari sekali.

Percobaan kecernaan ini dilakukan dengan metode koleksi total. Penelitian berlangsung dalam 2 tahap dengan 2 periakuan, setiap tahap terdiri dari 14 hari periode adaptasi dan 7 hari periode koleksi. Adapun rancangan pelaksanaan percobaan seperti terlihat berikut

\begin{tabular}{|c|c|c|c|}
\hline \multirow{2}{*}{ Tahap } & \multicolumn{3}{|c|}{ Sapi } \\
\cline { 2 - 4 } & $\mathrm{A}$ & $\mathrm{B}$ & $\mathrm{C}$ \\
\hline $\mathrm{I}$ & $\mathrm{P} 1$ & $\mathrm{P} 2$ & $\mathrm{P}$ I \\
\hline II & $\mathrm{P} 2$ & $\mathrm{P}$ I & $\mathrm{P}$ \\
\hline
\end{tabular}

Keterangan: P $1=$ konsentrat $1 \% \mathrm{BB}+$ rumput raja $100 \%$ dan P2 - konsentrat $1 \% \mathrm{BB}+$ rumput raja $30 \%+$ silase $70 \%$. 
Ransum diberikan 2 kali sehari yaitu pukul 08.00 dan 16.00 . Pemberian konsentrat dilakukan sebelum hijauan. Air minum diberikan secara ad libium.

Setiap tahap terdiri dari dua periode yaitu

Periode adaptasi. Pada periode ini ternak percobaan dibiasakan dengan lingkungan, kandang dan pakan yang akan digunakan. Dilakukan pemberian obat cacing. Pakan yang akan diuji sudah mulai diberikan secara bertahap dengan menggantikan sebagian dari pakan asalnya., Memasuki periode pendahuluan yang merupakan rangkaian dari periode adaptasi dilakukan pencatatan pemberian dan sisa pakan. Setelah pakan yang dicobakan stabil, maka periode koleksi data dapat dimulai.

Periode koleksi. Selama periode ini dilakukan pengumpulan sampel pakan, sisa pakan dan feses. Pengambilan sampel pakan dan sisa pakan dilakukan 2 hari sebelum periode koleksi sampai 2 hari sebelum periode koleksi berakhir. Konsentrat diambil sampelnya setiap pembelian baru. Sisa pakan diambil sebanyak $5 \%$ kemudian dikeringkan (oven $60^{\circ} \mathrm{C}$ ). Feses ditampung selama 24 jam kemudian ditimbang, dicampur merata dengan menggunakan mixer dan diambil sampel $2 \%$ kemudian dikeringkan dalam oven $60^{\circ} \mathrm{C}$. Pada akhir periode koleksi dilakukan komposit sampel pakan, sisa pakan dan feses per sapi per periode kemudian digiling dengan willey mill dengan diameter lubang saringan $1 \mathrm{~mm}$ untuk analisis

Variabel yang diamati meliputi: konsumsi dan kecernaan BK, BO, PK, NDF dan ADF, lama makan (menit), frekuensi remas-tikasi dan lama ruminasi. Data yang diperoleh antara perlakuan pakan rumput raja dan silase rumput raja di analisis statistik dengan Student's T-test (Steel dan Torrie, 1991)

\section{Hasil dan Pembahasan}

- Hasil analisis komposisi kimia pakan yang digunakan dalam penelitian tertera dalam Tabel 1.

Dari Tabel 1 terlihat bahwa kandungan nutrien pakan yang digunakan cukup bervariasi. Silase memiliki kandungan BK dan ADF yang lebih tinggi daripada rumput raja sedangkan kandungan $\mathrm{BO}, \mathrm{PK}$ dan NDF nya lebih rendah. Kandungan nutrien rumput raja yang digunakan dalam penelitian lebih tinggi daripada kandungan nutrien rumput raja yang dilaporkan Yanuarianto (1998) yaitu $\mathrm{BK}$ $13,12 \%$, BO $89,20 \%$ BK, ${ }^{4} \mathrm{PK} 7,75 \%$ BK, NDF $68,20 \%$ BK dan ADF $39,18 \%$ BK. Perbedaan ini diduga disebabkan karena perbedaan umur potong dan media tempat penanaman rumput raja (Crowder dan Chheda, 1982).

Tabel 1. Komposisi kimia pakan yang digunakan dalam penelitian (Chemical composition of feedstuff given during the feeding trial)

\begin{tabular}{|c|c|c|c|}
\hline \multirow{2}{*}{$\begin{array}{c}\text { Komposisi kimia pakan } \\
\text { Chemical composition }(\% \text { BK) }\end{array}$} & \multicolumn{3}{|c|}{ Jenis Pakan (Feedstuff) } \\
\hline & $\begin{array}{l}\text { Rumput raja } \\
\text { (King grass) }\end{array}$ & $\begin{array}{c}\text { Silase } \\
\text { (Silage) }\end{array}$ & $\begin{array}{l}\text { Konsentrat } \\
\text { (Concentrate) }\end{array}$ \\
\hline Bahan kering (Dry matter) & 11,81 & 23,95 & 86,56 \\
\hline Bahan organik (Organic matter) & 89,71 & 88.37 & 89,43 \\
\hline Protein kasar (Crude protein) & 10,67 & 8,73 & 15,89 \\
\hline NDF & 72,70 & 70,16 & 28,31 \\
\hline ADF & 43,52 & 44,70 & 22,15 \\
\hline
\end{tabular}


Kandungan BK silase lebih tinggi daripada rumput raja $(23,95$ vs $11,81 \%$ ) karena pada proses pembuatan silase dilakukan pelayuan hingga kandungan BK mencapai $35 \%$. Dengan demikian terjadi penurunan kandungan BK dari $35 \%$ menjadi $23,95 \%$. Hal ini terjadi karena dalam ensilase karbohidrat mudah larut difermentasi untuk pembentukan asam. Selain itu penurunan BK ini diduga disebabkan karena dalam proses respirasi juga dihasilkan air sehingga BK menurun. Penurunan kandungan BO disebabkan karena adanya aktivitas fermentatif bakteri yang menguraikan karbohidrat dan protein (McDonald, 1981). Penurunan kandungan nutrien silase (PK) umum terjadi sebagaimana dilaporkan Watson dan Nash (1960) yang disitasi McDonald (1981) bahwa kehilangan N pada ensilase dapat mencapai 15,2\%.

Rerata konsumsi dan kecernaan BK, $\mathrm{BO}, \mathrm{PK}, \mathrm{NDF}$ dan ADF sapi $\mathrm{PO}$ yang diberi perlakuan $\mathrm{P} 1$ : konsentrat $1 \% \mathrm{BB}+$ rumput raja $100 \%$ dan P 2 : konsentrat $1 \%$ BB + rumput raja $30 \%+$ silase $70 \%$ tertera dalam Tabel 2.

Konsumsi mutrien $\mathrm{P}_{2}$ berbeda sangat nyata $(P<0,01)$ lebih tinggi dibandingkan dengan konsumsi nutrien P1. Peningkatan ini disebabkan karena perbedaan tekstur silase yang relatif lebih lunak disamping karena kandungan BK silase yang lebih tinggi. Jackson dan Forbes (1970) menyatakan bahwa tingginya konsumsi pada silase rumput disebabkan karena tingginya kandungan BK. Kemampuan mengkonsumsi suatu bahan pakan dapat memberikan gambaran palatabilitas pakan tersebut atau sejauh mana pakan disukai oleh ternak (Yanuarianto, 1998) Konsumsi pakan sangat dipengaruhi oleh komposisi kimianya terutama kadar BK dan BO (Orskov, 1997; Davies et al., 1981). Konsumsi BK, BO, PK, NDF dan ADF rumput raja dan silase pada sapi $\mathrm{PO}$ ditunjukkan pada Gambar 1.

Tabel 2. Konsumsi dan kecernaan BK, BO, PK, NDF dan ADF sapi PO yang diberi pakan P1 dan P2 (Feed intake and digestibility of $D M, O M, N D F$ and $A D F$ of cattle given ration PI and P2)

\begin{tabular}{|c|c|c|c|c|}
\hline \multirow{2}{*}{\multicolumn{2}{|c|}{$\begin{array}{l}\text { Variabel Pengamatan } \\
\text { (Parameters measured) }\end{array}$}} & \multicolumn{2}{|c|}{ Jenis Pakan (Feed offered) } & \multirow{2}{*}{$\begin{array}{l}\text { Signifikansi } \\
\text { (Significance) }\end{array}$} \\
\hline & & PI & $\mathrm{P} 2$ & \\
\hline Konsumsi & BK & 85,12 & 103,18 & 0,01 \\
\hline Feed Intake & $\mathrm{BO}$ & 73,83 & 93,38 & 0,01 \\
\hline \multirow[t]{3}{*}{$\left(\mathrm{g} / \mathrm{kg} \mathrm{BB} \mathrm{B}^{0,75} /\right.$ hari $)$} & PK & 11,49 & 13,00 & 0,01 \\
\hline & NDF & 42,19 & 52,07 & 0,01 \\
\hline & ADF & 27,57 & 36,29 & 0,01 \\
\hline Kecernaan (\%) & BK & 64,14 & 68,76 & 0,01 \\
\hline \multirow[t]{4}{*}{ Digestibility } & $\mathrm{BO}$ & 65,01 & 70,37 & 0,01 \\
\hline & PK & 79,09 & 86,77 & 0,01 \\
\hline & NDF & 50,23 & 56,90 & 0,01 \\
\hline & $\mathrm{ADF}$ & 36,82 & 53,08 & 0,01 \\
\hline
\end{tabular}
$100 \%$ and)

$\mathrm{P} 1=$ konsentrat $1 \% \mathrm{BB}+$ rumput raja $100 \%$ dan (Concentrate $1 \% \mathrm{BW}+$ Kinggrass

P $2=$ konsentrat $1 \% \mathrm{BB}+$ rumput raja $30 \%+$ silase $70 \%$. (Concentrate $1 \% \mathrm{BW}+$ Kinggrass $30 \%$ - Silage $70 \%$ ). 


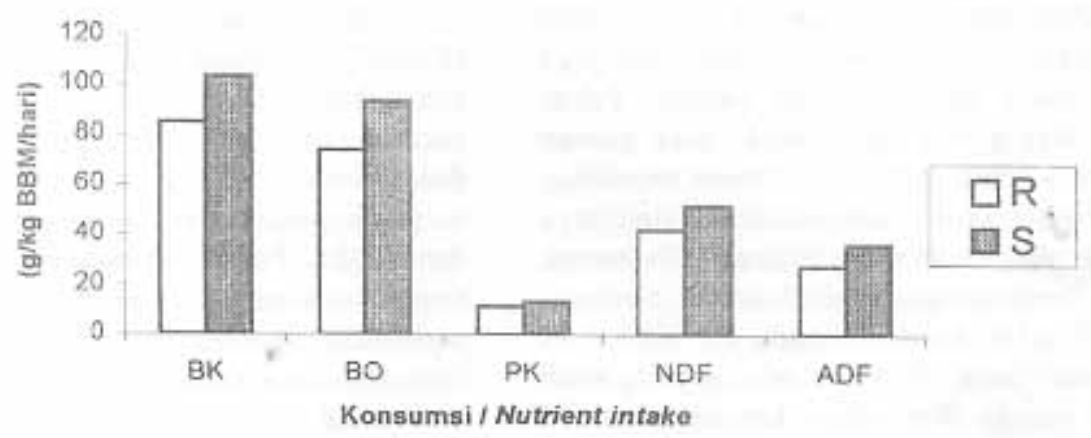

Gambar 1. Grafik konsumsi BK, BO, PK, NDF dan ADF pakan P1 dan P2 (Nutrients (DM, OM, CP, NDF and $A D F)$ intake of ration $P I$ and $P 2$ ).

Tabel 3. Rerata waktu makan dan aktivitas ruminasi sapi PO yang diberi pakan P1 dan P2 (Average of time for feeding activity and chewing activity of $P O$ cattle given ration $P I$ and $P 2$ )

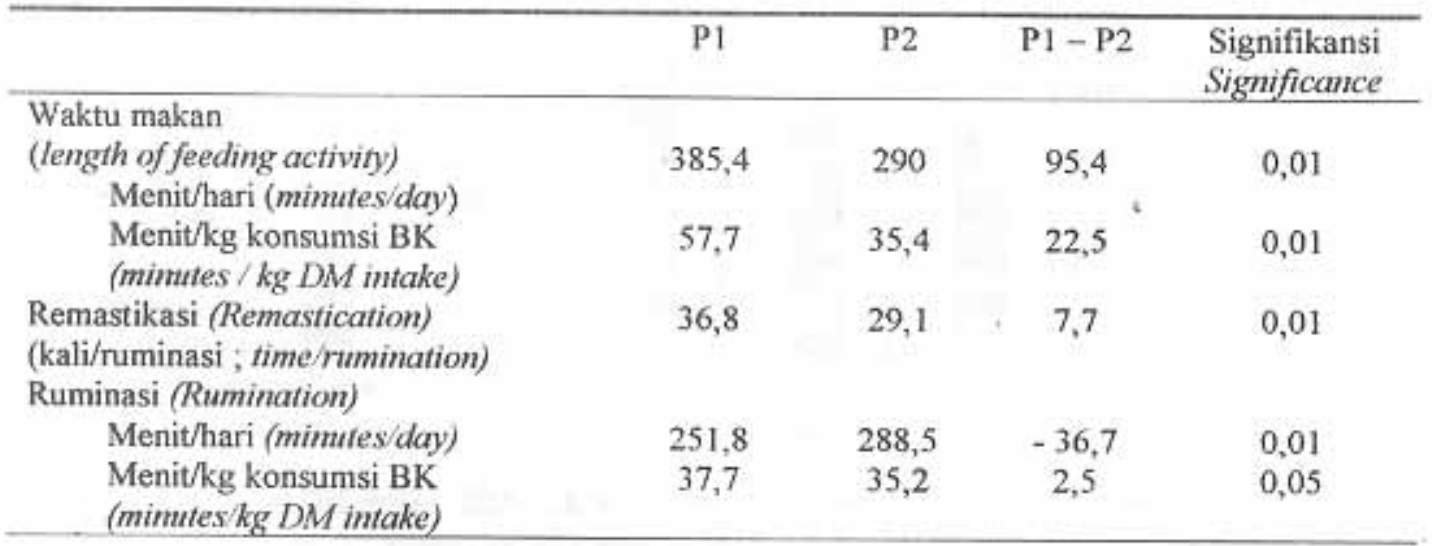

Keterangan: $\quad \mathrm{P} 1=$ konsentrat $1 \% \mathrm{BB}+$ rumput raja $100 \%$ dan

P 2 = konsentrat $1 \% \mathrm{BB}+$ rumput raja $30 \%+$ silase $70 \%$.

Menurut Chuzaemi (1994) konsumsi dan kecernaan juga ditentukan oleh kecepatan proses mastikasi. Data waktu makan dan remastikasi sapi $\mathrm{PO}$ dengan pakan $\mathrm{P} 1$ dan $\mathrm{P} 2$ disajikan pada Tabel 3.

Semakin lamanya waktu makan P1 terjadi karena bentuk fisiknya yang lebih keras sehingga kemungkinan jumlah yang dapat dikonsumsi dalam satuan waktu yang sama akan lebih sedikit. Hal ini berbeda dengan P2 yang mempunyai tekstur yang lebih lunak yang akan memudahkan prehensi dan kandungan BK yang lebih tinggi yang menyebabkan konsumsi BK per satuan waktu yang sama lebih banyak sehingga waktu makannya lebih singkat. Waktu yang diperlukan untuk mengkonsumsi per $\mathrm{kg}$ P2 lebih sedikit $(\mathrm{P}<0,01)$ dibanding $\mathrm{Pl}(35,4$ vs 57,7 menit). Teller et al. (1990) melaporkan bahwa waktu makan/hari silase ryegrass segar 
dan yang dilayukan masing-masing adalah 474.8 menit dan 383,5 menit atau 7 jam 55 menit dan 6 jam 24 menit. Hasil ini dapat dianalogkan dengan rumput raja dan silase pada penelitian ini. Jumlah remastikasi juga erat kaitannya dengan tekstur pakan. Pakan dengan tekstur yang lebih lunak maka jumlah remastikasi lebih sedikit. Proses mastikasi yang lebih cepat menyebabkan tingginya konsumsi dan kecernaan hijauan (Chuzaemi, 1994). Berdasarkan Tabel 3 waktu ruminasi pakan P2 lebih lama daripada P1 $(288,5$ vs $251,8 \mathrm{menit} / \mathrm{hari})$. Waktu ruminasi yang lebih lama ini diduga disebabkan karena tingginya BK yang dikonsumsi, sedangkan waktu ruminasi per $\mathrm{kg}$ BK yang dikonsumsi untuk pakan P2 lebih cepat daripada P1 karena tekstur P2 yang lebih lunak. Berdasarkan data kecernaan dari Tabel 2 dapat dibuat grafik kecernaan BK, BO, PK, NDF dan ADF pakan P1 dan P2 pada sapi PO sebagaimana pada Gambar 2.

Kecernaan nutrien $\mathrm{P} 2$ lebih tinggi $(\mathrm{P}<0,01)$ daripada $\mathrm{P} 1$. Kecernaan nutrien silase hasil penelitian lebih rendah daripada kecernaan nutrien silase yang dilaporkan Petit dan Veira (1994) sebesar 71,$9 ; 68,8$ dan 70,1 $\%$ masing-masing untuk kecernaan BK, NDF dan ADF. Perbedaan ini disebabkan karena tingginya kecernaan NDF dan ADF akibat perbedaan spesies rumput yang digunakan. Donalson dan Edwards (1976) yang disitasi McDonald (1981) menyatakan bahwa terjadi peningkatan kecernaan $\mathrm{BK}, \mathrm{BO}$ dan $\mathrm{N}$ pada rumput ryegrass yang di buat silase. Data kecernaan tersebut sebagaimana tercantum dalam Tabel 4.

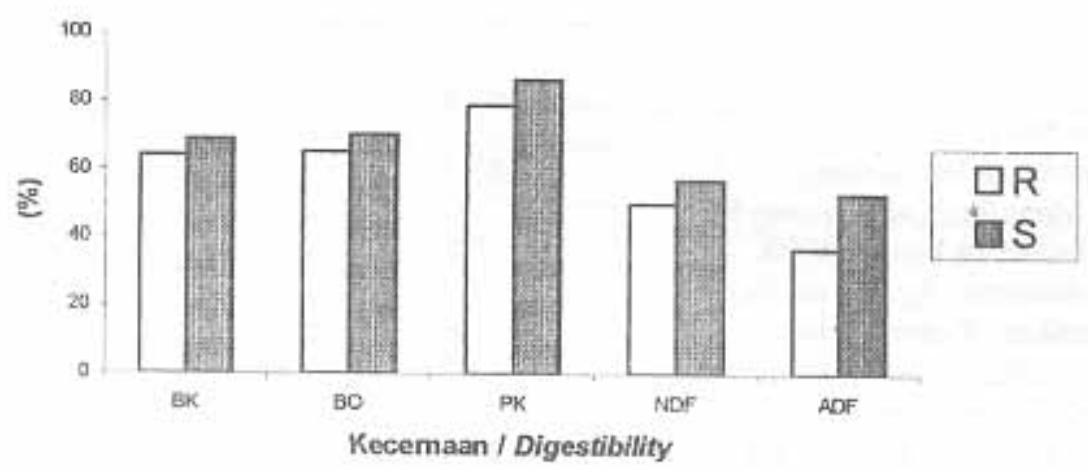

Gambar 2. Kecernaan BK, BO, PK, NDF dan ADF pakan P1 dan P2 (Digestibility of DM, OM, CP. NDF and ADF of ration PI and P2).

Tabel 4. Kecernaan nutrien rumput ryegrass dan silase ryegrass (McDonald, 1981) (Nutrients digestibility ryegrass and silage of reygrass (McDonald, 1981))

\begin{tabular}{lccc}
\hline Kecernaan (Digestibility) (\%) & $\begin{array}{c}\text { Ryegrass Segar } \\
\text { (Fresh Ryegrass) }\end{array}$ & \multicolumn{2}{c}{$\begin{array}{c}\text { Silase Ryegrass (Silage) } \\
\text { Aditif asam laktat }\end{array}$} \\
\hline Bahan Kering (Dary matter) & & 78,4 & $\begin{array}{c}\text { Pelayuan } \\
\text { (Dried) }\end{array}$ \\
Bahan Organik (Organic matter) & 79,7 & 79,4 & 75,2 \\
Nitrogen (Nitrogen) & 75,2 & 80,9 & 76,8 \\
\hline
\end{tabular}


NDF dan ADF silase lebih mudah dicerna sehingga silase mempunyai kecernaan yang lebih tinggi. Tingginya kecernaan serat ini diduga karena adanya inokulum bakteri selulolitik pada $\mathrm{ABB}$ yang digunakan. Bakteri ini bekerja pada awal ensilase dengan memecah selulosa dan hemiselulosa menjadi gula sederhana sehingga akan meningkatkan ketersediaan karbohidrat mudah larut dan sekaligus meningkatkan kecernaan serat. Menurut McDonald (1981) pembuatan silase akan meningkatkan kecernaan serat jika fermentasi ekstensive terjadi. Suwarso (1999) melaporkan bahwa penambahan inokulum bakteri seluiolitik pada silase rumput raja akan meningkatkan kecernaan BK masingmasing $30,5 \%$ dan $32,6 \%$ untuk kontrol dan level inokulum $10 \%$ BK. Schneider dan Flatt (1975) menyatakan bahwa ensilase akan meningkatkan kecernaan silase jika proses fermentasi terjadi dengan baik demikian juga dengan kucernaan PK. Hal senada juga diungkapkan oleh Koodela dan Schneiberg (1930) yang disitasi Sehneider dan Flatt (1975) bahwa meskipun silase kehilangan sebagian nutrien yang mudah tercerna namun semua nutrien dalam silase menjadi lebih mudah dicerna daripada hay. Peningkatan kecernaan fraksi serat (NDF dan ADF) pada silase ini akan berpengaruh pada tingginya kecernaan fraksi BK dan BO.

\section{Kesimpulan}

Berdasarkan basil penelitian yang telah dilakukan dapat disimpulkan bahwa penambahan aditif biologis Biomikro pada pembuatan silase memberikan konsumsi dan kecernaan silase yang lebih tinggi dibandingkan hijauan segar, dengan aktivitas ruminasi yang lebih efisien:

\section{Daftar Pustakat}

Chuzacmi, S. 1994. Potensi Jerami Padi Sebagai Pakan Ternak Ditinjau Dari Kinetika Degradasi dan Retansi Jerami
Di Dalam Rumen. Disertasi S3 Universitas Gadjah Mada, Yogyakarta. Crowder, I. V, and H, R Chheda. 1982. Tropical Grassland Husbandry. Longman Group Limited, New York.

Davies, H L., 1. D Hume and R. G. Packham. 1982. A Course Manual in Nutrition and Growth AUIDP, Australia.

Hartadi, H. 1992. Fermentasi silase sorghum biji dan kedelai yang ditanam tumpang sari Buletin Peternakan, 16 98-103.

Jackson, $N$ and T, J. Forbes, 1970. The voluntary intake by cattle of four silages differing in dry matter content. 1. Anim. Prod, 12 ; 591-599.

McDonald, P. 1981. Biochemistry of Silage John Wiley and Sons, New York.

Orskov, E. R 1997. The Feeding of Ruminants Principles and Practise. Chainmbe Publications. Rowett Research Institute, Aberdeen.

Petit, H V and D. M. Veira. 1994. Digestion characteristics of beef steers fed silage and different levels of energy with and without protein supplementation. J. Anim Sci, $72: 3213-3220$,

Schneider, B. H, and W. P. Flatt. 1975. The Evaluation of Feeds through Digestibility Experiments. The University of Georgia Press. Athens.

Steel. R. G D and J H Torrie, 1991. Prinsip dan Prosedur Statistik Suatu Pendekatan Biometrik. PT Gramedia Pustaka Utama, Jakarta

Suwarso, J. 1999 Screening Mikrobia Sellulolitik Aerobik dari Effective Microorganism-4 dan Aplikasinya Pada Silase Rumput Raja. Tesis S2. Program Pascasarjana. Universitas Gadjah Mada, Yogyakarta.

Teller, E., M. Vanbelle, P. Kamatali, and J. Wavreille. 1989. Intake of direct cut or wilted grass silage as related to chewing behaviour ruminal characteristics and site and extent of digestion by heifers $J$. Anim Sci. $68: 3897-3904$ 
Van Soest, P. J. 1994. Nutritional Ecology of the Ruminant. Second Edition. Cornell University Press. Ithaca and London.

Yanuarianto, O. 1998. Konsumsi dan Kecernaan Pakan Tunggal Jerami
Kacang Tanah, Rumput Raja dan Hijauan Jagung pada Sapi Peranakan Ongole. Tesis S2. Program Pascasarjana. Universitas Gadjah Mada, Yogyakarta. 